\title{
MENINGKATKAN KEMAMPUAN PEMECAHAN MASALAH MATEMATIS SISWA MELALUI PENERAPAN MODEL PEMBELAJARAN NOVICK
}

\author{
Sri Rezeki \\ Program Studi Informatika, Universitas Indraprasta PGRI \\ srezeki40@gmail.com
}

\begin{abstract}
Abstrak
Penelitian ini bertujuan menelaah tentang masalah peningkatan pemecahan masalah matematis siswa melalui penerapan model pembelajaran Novick. Populasi dalam penelitian ini adalah seluruh siswa SMA kelas X pada salah satu SMA Swasta di kota Bandung, dengan sampel dua kelas yang terdiri dari kelas eksperimen dan kelas kontrol. Pengambilan sampel diambil dengan menggunakan teknik purposive sampling. Analisis data dilakukan secara kuantitatif. Analisis data yang dilakukan terhadap data pre-test, post-test dan rataan N-Gain antara kedua kelompok sampel dengan menggunakan uji $t$. Hasil penelitian dari hasil pengujian akhir di peroleh thitung $>$ t-tabel $(0,052<0,05)$ menunjukkan bahwa peningkatan pemecahan masalah matematis siswa yang mendapatkan pembelajaran melalui model pembelajaran Novick lebih baik daripada siswa yang mendapatkan pembelajaran konvenisonal.

Kata kunci : Pembelajaran matematika, Pembelajaran Novick, kemampuan pemecahan masalah matematis
\end{abstract}

\begin{abstract}
This study aims to examine the problem of increasing students' mathematical problem solving through the application of Novick's learning model. The population in this study were all high school students of class $X$ in one of the private high schools in the city of Bandung, with a sample of two classes consisting of the experimental class and the control class. Sampling was taken using a purposive sampling technique. Data analysis is carried out quantitatively. Data analysis was performed on pre-test, post-test and N-Gain data between the two sample groups using the $t$ test. The results of the final test were calculated>t-table $(0.052<0.05)$ indicating that the improvement of mathematical problem solving of students who get learning through the Novick learning model is better than students who get conventisonal learning.

Keywords: Mathematics learning, Novick learning, mathematical problem solving skills
\end{abstract}

\section{PENDAHULUAN}

Matematika merupakan ilmu universal yang mendasari perkembangan teknologi modern yang bisa menjadi tolak ukur kemajuan suatu negara, misalnya dalam perkembangan ilmu komputer. Di samping itu, matematika mempunyai peranan penting dalam berbagai disiplin ilmu dan memajukan daya pikir manusia, karena matematika dapat mengembangkan logika berpikir dan membentuk sikap kritis dan kreatif seseorang.

Namun saat ini matematika masih menjadi mata pelajaran yang sulit bagi siswa. Siswa masih kesulitan dalam menyelesaikan soal-soal yang diberikan guru. Dalam proses pembelajaran guru masih cenderung menggunakan buku teks, menjelaskan materi, dan pemberian latihan kepada siswa. Hal ini menyebabkan siswa kurang aktif dalam pembelajaran dan mengkonstruksi konsep-konsep awal yang telah dibangun. Model pembelajaran seperti ini tentunya menjadi kurang efektif untuk membangun kemampuan matematis siswa.

Ini merupakan tantangan bagi guru matematika untuk mengembangkan 
suatu model pembelajaran matematika dan mengembangkan kemampuan matematis siswa, sehingga proses pembelajaran lebih menarik dan inovasi. Salah satu kemampuan matematis siswa yang dapat dikembangkan oleh guru yaitu kemampuan pemecahan masalah matematis siswa. Dengan mengembangkan kemampuan matematis siswa ini, diharapkan dapat mendorong siswa untuk berpikir secara matematis, logis, dan sistematis. Melalui cara berpikir tersebut, dapat membentuk pola pikir siswa terhadap kemampuan matematis dalam kegiatan matematika, sehingga dapat memotivasi siswa untuk menerapkannya dalam kehidupan seharihari.

Pemecahan masalah merupakan bagian dari kurikulum matematika yang sangat penting karena dalam proses pembelajaran maupun penyelesaian, siswa dimungkinkan memperoleh pengalaman menggunakan pengetahuan serta keterampilan yang sudah dimiliki untuk diterapkan pada pemecahan masalah yang bersifat tidak rutin [6]. Melalui kegiatan ini aspek-aspek kemampuan matematika penting seperti penerapan aturan pada masalah tidak rutin, penemuan pola, penggeneralisasi, komunikasi matematika, dan lain-lain dapat dikembangkan secara lebih baik. [3] juga menegaskan pentingnya pemecahan masalah yang menyatakan bahwa pemecahan masalah merupakan bagian integral dalam pembelajaran matematika, sehingga hal tersebut tidak boleh dilepaskan dari pembelajaran matematika.

Adapun $\begin{gathered}\text { indikator } \\ \text { kemampuan }\end{gathered}$ pemecapaian
matematis siswa pada penelitian ini
adalah

a. Kemampuan asosiasi, yaitu menghubungkan antara ide dan data yang diketahui, memilih data yang relevan terhadap masalah yang diberikan, dan membuat representasi matematis dari masalah yang diberikan.

b. Kemampuan analisis, yaitu memilih dan menerapkan strategi pemecahan masalah yang digunakan, menyelesaikan masalah yang tidak rutin, memeriksa kembali jawaban yang diperoleh, dan menginterpretasikan jawaban yang diperoleh

c. Kemampuan generalisasi, yaitu Menyusun kesimpulan dari penyelesaian masalah yang diperoleh dan membuat bentuk umum yang lebih sederhana dari jawaban yang diperoleh

Berdasarkan permasalahan di atas, maka perlu diterapkan suatu model pembelajaran yang dapat melibatkan siswa dalam pembelajaran matematika, sehingga dapat mengaktifkan interaksi antara siswa dan guru, siswa dan siswa, serta siswa dan bahan pelajarannya. Dengan demikian, pembelajaran matematika diarahkan pada aktivitas siswa yang terampil dalam menemukan dan memahami konsep-konsep atau prinsip-prinsip dalam matematika. Jika siswa telah memahami konsep matematika tersebut, maka mereka mampu memecahkan atau menyelesaikan soal-soal yang berkaitan dengan konsep matematika yang diajarkan. Salah satu solusi untuk memecahkan masalah tersebut dengan menerapkan salah satu model pembelajaran yaitu model pembelajaran yang dikembangkan oleh Nussbaum dan Novick, yang dikenal dengan model pembelajaran Novick.

Salah satu model pembelajaran yang dapat diterpakan untuk meningkatkan 
kemampuan pemecahan masalah siswa yaitu pembelajaran Novick.

Menurut referensi [2] adapun langkahlangkah pada model pembelajaran Novick yaitu sebagai berikut:

1. Fase Pertama, Exposing Alternative Framework (Mengungkap Konsepsi Awal)

Terdapat dua hal utama yang perlu dilakukan pada fase pertama ini:

a. Mengungkap konsepsi awal siswa

Pengetahuan awal yang dimiliki siswa bisa benar atau salah, untuk itu perlu dilakukan langkah mengungkapkan gagasan atau ide siswa dalam proses pembelajaran, hal ini bertujuan agar terjadinya perubahan konseptual siswa.

b. Mendiskusikan dan mengevaluasi konsepsi awal siswa

Tujuan langkah ini adalah untukk memperjelas dan meninjau konsepsi awal para siswa melalui diskusi kelompok di kelas.

2. Fase Kedua, Creating Conceptual Conflict (Menciptakan Konflik Konseptual)

Proses konflik konseptual guru menciptakan situasi anomali, yaitu situasi yang bertentangan dengan pengetahuan awal siswa. Pada tahap ini diamati respon siswa terhadap situasi anomali yang diberikan. Fase inilah yang disebut fase konflik, di mana siswa mengalami pertentangan dalam struktur kognitifnya atas apa yang mereka ketahui sebelumnya dan fakta apa yang mereka lihat melalui demonstrasi atau percobaan yang mereka lakukan.
3. Fase Ketiga, Encouraging Cognitive Accommodation (Mengupayakan Terjadinya Akomodasi Kognitif) Adapun syarat terjadinya akomodasi menurut Posner dkk yaitu:

1) Harus ada ketidakpuasan terhadap konsep yang telah ada (dissactifaction).

2) Konsep yang baru minimal harus dapat dimengerti (minimal understanding on intelligible), rasional, dan dapat dipergunakan untuk memecahkan persoalan atau fenomena baru.

3) Konsep yang baru harus masuk akal (initially plausibility), dapat memecahkan dan menjawab persoalan yang terdahulu, dan juga konsisten dengan teori-teori atau pengetahua yang sudah ada.

4) Konsep baru harus berdaya guna dan bermakna (fruitfulness) bagi fenomena yang lain atau penemuan baru.

\section{METODE}

Penelitian ini merupakan penelitian kuantitatif dengan menggunakan metode kuasi eksperimen. Pada studi ini subjek tidak di kelompokkan secara acak, tetapi keadaan subjek diterima sebagaimana adanya [5]. Menurut referensi [1] menyatakan bahwa untuk rancangan Quasi-Experimental dengan desain nonequivalent pre-test and post test control group design, kelompok eksperimen dan kelompok kontrol di seleksi tanpa proedur acak. Kedua kelompok tersebut sama-sama memperoleh pre-test dan post-test, akan tetapi kelompok eksperimen saja yang diberikan treatmen.

Pada kelas eksperimen menggunakan model pembelajaran Novick dengan, kelas kontrol menggunakan pembelajaran konvensional. Adapun 
desain penelitian ini diilustrasikan sebagai berikut:

$\begin{array}{lllr}\text { Kelas eksperimen } & \mathbf{O} & \mathbf{X} & \mathbf{O} \\ \text { Kelas konvensional } & \mathbf{O} & & \mathbf{O}\end{array}$

Dengan:

$$
\begin{aligned}
& \mathrm{X}= \text { Model pembelajaran Novick } \\
& \mathrm{O}= \text { pretest dan posttest } \\
& \text { pemecahan masalah matematis } \\
& \text { siswa. }
\end{aligned}
$$

Subjek penelitian ini adalah salah satu Sekolah Menengah Atas Swasta di Kota Bandung. Populasi penelitiannya adalah seluruh siswa kelas X. Populasi tersebut dipilih subjek sampel sebanyak dua kelas secara acak untuk dijadikan kelas penelitian. Pemilihan secara acak dimaksudkan karena semua kelas yang ada mempunyai kesempatan yang sama untuk dipilih sebagai kelas sampel. Karena desain penelitian menggunakan nonequivalent pre-test and post test control group design, maka penentuan sampel dilakukan dengan menggunakan teknik Purposive Sampling.

\section{HASIL DAN PEMBAHAN}

Berdasarkan hasil pengujian, uji normalitas skor $\mathrm{N}$-Gain diperoleh hasil signifikansi pada kelas eksperimen adalah 0,695 dan kelas kontrol adalah 0,318 . Dari nilai signifikan terlihat bahwa nilai signifikan kedua kelas lebih besar dari $\alpha=0,05$, sehingga terima $\mathrm{H}_{0}$. Ini menunjukkan bahwa peningkatan kemampuan pemecahan masalah matematis siswa pada kelas eksperimen dan kelas kontrol berdistribusi normal. Selanjutnya dilakukan uji homogenitas skor N-Gain dengan uji levene's diperoleh hasil signifikansi N-Gain kemampuan pemecahan masalah matematis siswa $0,041<0,05$, ini berarti bahwa $\mathrm{H}_{0}$ ditolak. Hal ini menunjukkan bahwa varians $\mathrm{N}$-gain kemampuan pemecahan masalah matematis pada kedua kelas tersebut tidak homogen. Kemudian dilakukan uji perbedaan rerata dengan uji $\mathrm{t}$ diperoleh t-hitung $>\mathrm{t}$ tabel $(0,052<0,05)$, artinya $\mathrm{H}_{0}$ ditolak. Ini berarti bahwa secara signifikan peningkatan kemampuan pemecahan masalah matematis siswa yang pembelajarannya menggunakan model pembelajaran Novick lebih baik daripada siswa yang pembelajarannya menggunakan pembelajaran konvensional. Jadi, dapat disimpulkan bahwa peningkatan kemampuan pemecahan masalah matematis siswa yang pembelajarannya menggunakan model pembelajaran Novick lebih baik daripada siswa yang pembelajarannya menggunakan pembelajaran konvensional.

Secara umum pembelajaran matematika melalui model pembelajaran Novick telah berjalan sesuai dengan yang diharapkan. Hasil pengamatan menunjukkan siswa terlihat lebih aktif dan berani untuk berdiskusi dengan teman sekelompoknya dan bertanya pada guru mengenai materi yang belum paham, serta aktif memberikan pertanyaan atau tanggapan saat diskusi kelas berlangsung. Sehingga dengan demikian peran guru mulai berkurang dalam pembelajaran dan hanya sebagai fasilitator dan motivator. Pembelajaran tidak lagi terpusat pada guru namun telah bergeser dimana siswa lebih aktif terlaibat dalam pembelajaran, sehingga secara perlahan siswa akan terbiasa untuk berusaha mengkonstruksi kemampuan matematika mereka sendiri berdasarkan permasalahan-permasalahan yang mereka hadapi.Salah satu kelebihan dari model pembelajaran Novick ini, yaitu siswa dapat mengkonstruksi pengetahuannya sendiri atas konsep yang sudah ada sehingga terjadinya perubahan konsep menuju konsep yang lebih ilmiah. Hal ini sejalan dengan teori 
konstruktivisme dalam pembelajaran yang dikembangkan oleh Piaget, yaitu pengetahuan dibangun oleh siswa sendiri dan siswa aktif mengkonstruksi secara terus menerus, sehingga terjadi perubahan konsep yang lebih rinci, lengkap serta sesuai dengan konsep ilmiah.

Penelitian serupa telah banyak dilakukan oleh berbagai pihak. Diantaranya penelitian yang dilakukan oleh [4] Penelitian ini bertujuan untuk mengetahui apakah kemampuan pemecahan masalah siswa dengan menerapkan model pembelajaran Novick berbantuan geogebra lebih tinggi daripada kemampuan pemecahan masalah siswa dengan menerapkan pembelajaran konvensional. Penelitian ini menggunakan pendekatan kuantitatif. Data dianalisi dengan t-tes dan lembar observasi. Hasil penelitian dengan pengujian hipotesis menggunakan uji $\mathrm{t}$ pada taraf signifikan $\alpha=0,05$ diperoleh thitung > t-tabel $(2,26>1,68)$, sehingga H0 ditolak dan Ha diterima. Hal ini menunjukkan bahwa kemampuan pemecahan masalah siswa yang diajarkan melalui model pembelajaran Novick berbantuan media Geogebra lebih baik daripada yang diajarkan dengan model pembelajran konvensional.

\section{SIMPULAN}

Simpulan dari hasil penelitian ini adalah dari hasil pengujian akhir di peroleh thitung $>$ t-tabel $(0,052<0,05)$, artinya $\mathrm{H}_{0}$ ditolak. Ini berarti bahwa secara signifikan peningkatan kemampuan pemecahan masalah matematis siswa yang pembelajarannya menggunakan model pembelajaran Novick lebih baik daripada siswa yang pembelajarannya menggunakan pembelajaran konvensional. Adapun saran dari hasil penelitian ini, bagi peneliti selanjutnya, disarankan untuk meneliti kemampuan matematis yang lainnya dengan menggunakan model pembelajaran Novick.

\section{DAFTAR PUSTAKA}

[1] John W. Creswell. Reserch Design: Pendekatan Kualitatif, Kuantitatif, dan Mixed. Edisi Ketiga. Yogyakarta: Pustaka Pelajar, 2010.

[2] M. Natsir. Strategi Penggunaan Model Pembelajaran Novick untuk Meningkatkan Keaktifan dan Pemahaman Siswa tentang Listrik dalam Pembelajaran IPA di SD. Tesis SPs UPI Bandung: Tidak Diterbitkan, 1997.

[3] National Council of Teacherof Mathematics. Principles and Standards for School Mathematics. Reston, VA: NCTM, 2000.

[4] Rahmi, Wahyuni. "Penerapan Model Pembelajaran Novick Berbantuan Media Geogebra Terhadap Kemampuan Pemecahan Masalah Siswa Pada Materi Persamaan Lingkaran."Jurnal Pendidikan Almusli, Edisi Khusus No. 3 pp 11-14, 2017.

[5] Ruseffendi, E.T. Dasar-Dasar Penelitian Pendidikan dan Bidang Non-Eksakta Lainnya. Bandung: Tarsito, 2010.

[6] Suherman, dkk. Strategi Pembelajaran Matematika Kontemporer. Bandung:FMIPA UPI, 2003. 